\title{
準マイクロ波帯用電波吸収リサイクルボードの開発 \\ DEVELOPMENT OF RECYCLING BOARD WITH ELECTROMAGNETIC WAVE ABSORPTION IN THE QUASI MICROWAVE BAND
}

\author{
河辺伸二*, 池田哲夫**，若田佳希***，小西正夫**** \\ Shinji KAWABE, Tetsuo IKEDA, Yoshiki WAKATA \\ and Masao KONISHI
}

\begin{abstract}
The electronic devices using electromagnetic wave increases recently. It has been important to study the electromagnetic compatibility inside building space.

In this paper, the recycling board using waste plastics and paper is developed and added electromagnetic wave absorption characteristic mixed with ferrite and carbon.

The better mix proportion of absorption is examined with parallel wire line method by small-size specimen. Large-size recycling board with electromagnetic wave absorption is made and has rather than $10 \mathrm{~dB}$ absorption characteristic of electromagnetic field strength in quasi microwave band. This board will be able to improve the complex condition in electromagnetic environment.
\end{abstract}

Keywords : Quasi microwave band, Return loss, Electric field strength, Parallel wire line, Ferrite, Carbon 準マイクロ波帯、反射減衰量、電界強度レベル、平行二線線路、フェライト、カーボン

\section{1.はじめに}

無線 LAN や携帯電話、地上波デジタル放送、高速道路のETC など の実用化に伴い、電磁環境は非常に多様化・複雑化している。一方、 電磁波が建築物内外で多重反射し高度電子機器の誤作動や、無線通 信システムの情報漏洩等の障害が発生している。このため、特定周 波数帯の電磁波の適切な送受信を可能とする建築空間内の通信環境 を整備する必要がある。この対策の 1 つして、建築壁面に電波吸 収体を設置して電磁波の多重反射を减少させる方法がある。

筆者らはこれまでに電波吸収体の測定・評価方法として、平行二 線線路を用いた測定法を提案し、この新測定方法を用いて多数の電 波吸収体の研究を行ってきた ${ }^{128)}$ 。特に参考文献 2)では、この平行 二線線路測定法を用いる準マイクロ波带の電波吸收特性の測定方法 を検討し、迅速かつ経済的に電波吸収体を開発する手法について述 べた。

また、近年ポリプロピレン (P.P. )、ポリエチレン (P. E. )、ポリ エチレンテレフタレート (P.E.T. ) などのプラスチックが大量に使 用され、これらの廃棄物の再資源化が重要視されている。筆者らは プラスチック廃棄物と古紙を混合し、熱間プレスにより成型するリ サイクルボードを開発中である。このボードの当初の使用目的は低 コストのコンクリート型枠や家具材などである。しかし、本研究で 電波吸収特性を付加することにより、高機能・高付加価值を有する 電波吸収リサイクルボードとすることを考えている。

* 名古屋工業大学大学院 助教授・工博

** 名古屋工業大学 名誉教授. 工博

*** 名古屋工業大学 大学院生

*****
本研究は筆者らの一連の成果をもとに、実用化への応用の第一歩 として、今後益々多様化してくる準マイクロ波帯における電波吸収 リサイクルボードを作製し、この電波吸収特性を評価・検郡する。 本研究では、1）プラスチック廃棄物と古紙を利用したリサイク ルボードに、電波吸収材料のカーボンとフェライトを混入して、準 マイクロ波帯用の電波吸収リサイクルボードを開発する。2）寸法 $70 \mathrm{~mm} \times 120 \mathrm{~mm}$ 、厚さ $10 \mathrm{~mm}$ から $20 \mathrm{~mm}$ の小型電波吸収リサイクルボー ドを試作し、平行二線線路測定法を用いて良好な電波吸收特性を有 する電波吸収リサイクルボードの調合を見いだす。3）電波吸収性 能の良好な調合について、寸法 $600 \mathrm{~mm} \times 1800 \mathrm{~mm}$ 、厚さ $15 \mathrm{~mm}$ の大型 電波吸収リサイクルボードを作製し、このボードの任意の位直から 切り出した供試体と小型電波吸収リサイクルボードの電波吸収特性 を比較する。

電波吸収体の開発目標は、1) 簡易型携帯電話(PHS) の周波数帯で ある $1900 \mathrm{MHz}$ と無線LAN、電子レンジの周波数帯である $2450 \mathrm{MHz}$ にお いて反射減衰量が $20 \mathrm{~dB}$ 以上あること、2） $1700 \mathrm{MHz}$ から $2600 \mathrm{MHz}$ ま での広周波数帯域において反射減衰量が $10 \mathrm{~dB}$ 以上あること、3）電 波吸収リサイクルボードの厚さを $20 \mathrm{~mm}$ 以下をすことなどである。 本研究の成果は、電波吸収リサイクルボードを応用したオフィス 用電波吸収パーティションの開発を可能とし、IT機器を多用する複 雑化したオフィス内の電磁環境の改善に役立つものと考える。 
2. リサイクルボート゚

2.1 概要 (本研究の一部を参考文献 3)に示す。)

近年、プラスチックの統一化は徐々に図られているが、現在でも 多種多様なプラスチックが様々な仕様部位に用いられ、分別無くし てプラスチックのリサイクルは困難な状況にある。本研究のリサイ クルボードの作製においては、Fig. 1 に示すように、各々のプラス チックの融点の違いを利用してプラスチック廃辒物を溶融しながら、 かつ遠心力を用いてプラスチック廃㲤物を緎維化することにより、 多種雑多なプラスチック廃衰物を分別する無分別瀻維化工程を利用 する。本研究で用いる繊維化したプラスチック廃㲤物をPhoto 1 に 示す。縮れと不連続な太さの変化がこの䋐維の特徴である。

プラスチック廃棄物を瀻維化することにより、絡み合った瀻維と 繊維の隙間に粉末状の電波吸収材料を保持させることが可能となる。 一方、古紙も紙の繊維を切断してしまうシュレッダーで裁断するの ではなく、古紙の繊維質を残すようにほぐしている。

\section{2 作製方法}

リサイクルボードの作製方法の流れを Fig. 2 に示す。リサイクル ボードの作製方法における一連の工程は、粉砕工程、無分別繊維化 工程、混合工程、熱間プレス工程の 4 工程に分けられる。

(1) 粉砕工程 : Photo 2 に示す粉砕機を使用してプラスチック廃襄 物を粉砕し、次工程に対応する均一な大きさに調整する。

(2) 無分別繊維化工程 : Photo 3 に示すポリマーオリエンテーショ ン機を使用して粉砕後の多種雑多なプラスチックを溶融し、遠心力 を利用して延伸繊維化させる。この方式は、各々のプラスチックの 融点の違いを利用して、軟化・溶融したプラスチックを遠心力の作 用によって吐出することで、無選別で分別繊維化を可能とし、熱可 塑性樹脂を適材とする。ただし、本研究では設定温度を一定にして 1 種類のプラスチックを選別してリサイクルボードを作製している。 古紙は解繊し、繊維化する。この場合、切断するのではなく、引 き裂く様に解緎し古紙の瀻維の切断を防ぐ。

(3) 混合工程 : Photo 4に示寸ミキシングマシンを使用して緎維化 したプラスチックと古紙を㹂拌し、電波吸収材料であるカーボンと フェライトを混ぜて均一に混合する。

(4) 熱間プレス工程 : Photo 5 に示す熱間プレス機を使用する。混 合工程で混合した原料を、熱間プレス機にて加熱・加圧して、ボー ド化する。加熱温度は、今回の実験で使用するP.P. の融点(約 160 $\left.{ }^{\circ} \mathrm{C}\right)$ を考虑して $225^{\circ} \mathrm{C}$ とする。1MPa で加圧し、プレス時間は厚さ 15 m m 12 分を標準とする。この結果、リサイクルボードは釘打ち、鋸 引き、曲げ加工が可能である。

電波吸収材料を混入してボード化する場合、電波吸収材料を層状 に重ねる方法と全体に均等に分布させる方法があるが、層状に重ね る方法はボードの層剥がれを起こしやすいため、本研究では後者を 用いることとした。絡み合った繊維と繊維の隙間に粉末状の電波吸 収材料を混入させることにより、ボードの全体に均等に電波吸収材 量を分布させることが可能である。なお、今回の研究において使用 するプラスチック廃辌物はP.P. とする。混入材料はカーボン(密度： $2.0\left[\mathrm{~g} / \mathrm{cm}^{3}\right]$ 、粒径 $: 10 \mu \mathrm{m}$ 以下) とフェライト(密度: $5.0\left[\mathrm{~g} / \mathrm{cm}^{3}\right]$ 、平均 粒子径: $1.23 \mu \mathrm{m})$ の 2 種類の粉末とする。

将来は、電波吸収材料も産業廃棄物を利用し、電波吸収リサイク ルボードの原料は全て廃棄物で構成するように目指す。

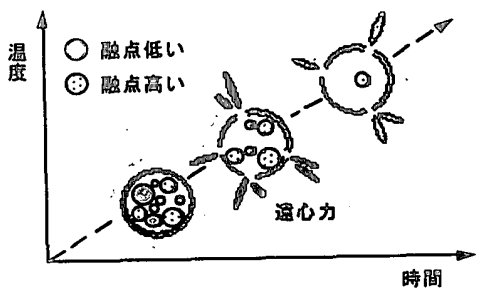

Fig. 1 溶融温度の蛙いによる分別 と遙心力による緎維化の概念图

Photo 1 緛維化した プラスチック廃栾物

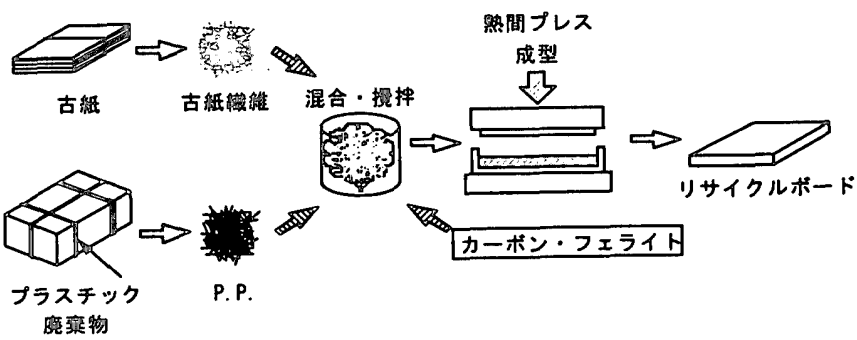

Fig. 2 霓波吸収リサイクルボードの作製方法

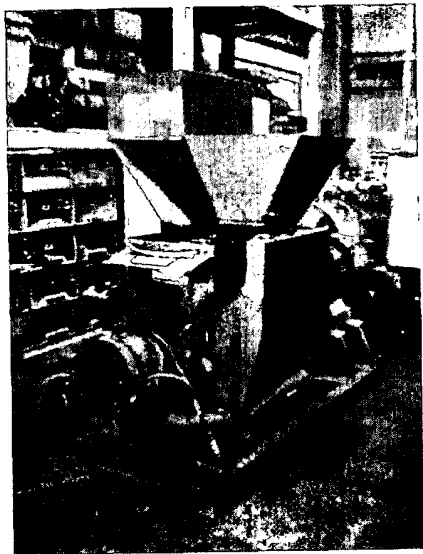

Photo 2 紛群機 (妢碎工程)

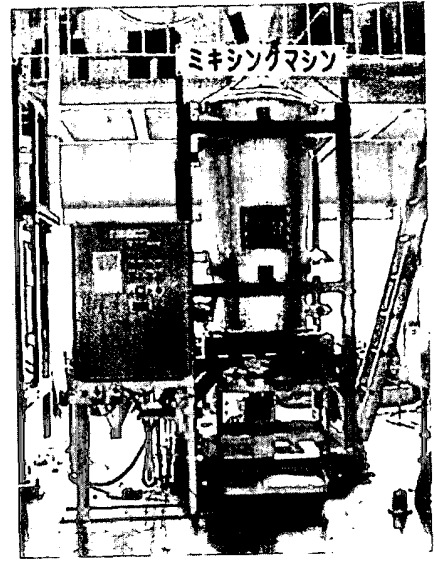

Photo \& ミキシングマシン (混合工程)

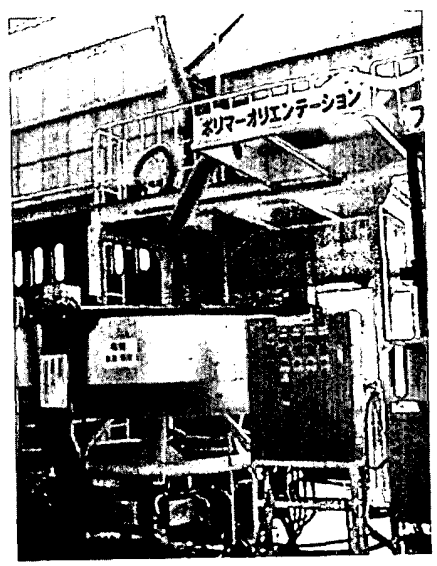

Photo 3 ポリマー オリエンテーション機

(無分別織維化工程)

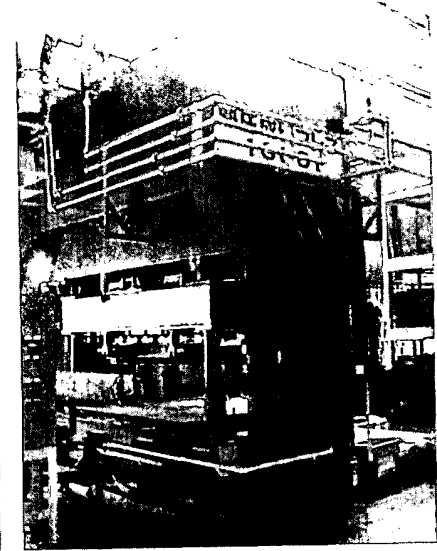

Photo 5 熱間プレス機 (俱間プレスエ程) 


\section{3．準マイクロ波帯用の平行二線線路測定法}

\section{1 装置概要}

平行二線線路測定法は、フェライトやカーボンなどの電波吸収材 料を混入した複合材料のボード状供試体の測定に適している。淮マ イクロ波带用の平行二線線路測定装置の概要をFig. 3 に示す。装置 の詳細は参考文献 2) に示す。 $1900 \mathrm{MHz}$ から $2450 \mathrm{MHz}$ の測定周波数を 考虑して、測定装置に用いる線路は直径 $1 \mathrm{~mm}$ の銅線とし、二線の間 隔は $10 \mathrm{~mm}$ とする。また、測定時の安定性向上や線路を整合状態にす るために線路の特性インピーダンスに等しい $390 \Omega$ の抵抗と金属反 射板を設置する。送信アンテナは線路上で固定する。受信アンテナ は線路下を自由に滑らすことが可能で、供試体からの距離とその位 置での電圧定在波を測定する。

\section{2 測定方法}

供試体を準マイクロ波帯用の平行二線線路測定装置に設置し、測定 対象である $1900 \mathrm{MHz} 、 2450 \mathrm{MHz}$ を含む $1700 \mathrm{MHz}$ から $2600 \mathrm{MHz}$ における 淮マイクロ波帯の範囲で電圧定在波を測定する。電圧最大値Vmax. と 電圧最小值 Vmin。 を求め、測定値を式 (1)、(2)、(3) を用いて計算し、 電圧定在波比 $(\rho)$ 、反射係数 $(|S|)$ 、反射減衰量 $(R L)$ を求める。

$$
\begin{aligned}
& \rho=10 \\
& |\mathrm{~S}|=\frac{\rho-1}{\rho+1} \\
& \mathrm{RL}=-20 \log |\mathrm{S}|[\mathrm{dB}]
\end{aligned}
$$

\section{4.小型電波吸収リサイクルボード}

\section{1 実験内容}

大型電波吸収リサイクルボードを作製する前に、比較的作製しや すい小型電波吸収リサイクルボードにより、平行二線線路測定法を 用いて反射减衰量を測定する。混入材料や混入量の違いによる反射

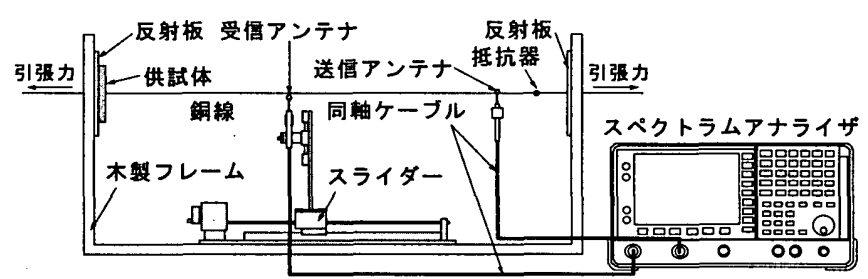

\section{Fig. 3 準マイクロ波帯用の平行二線線路測定装置}

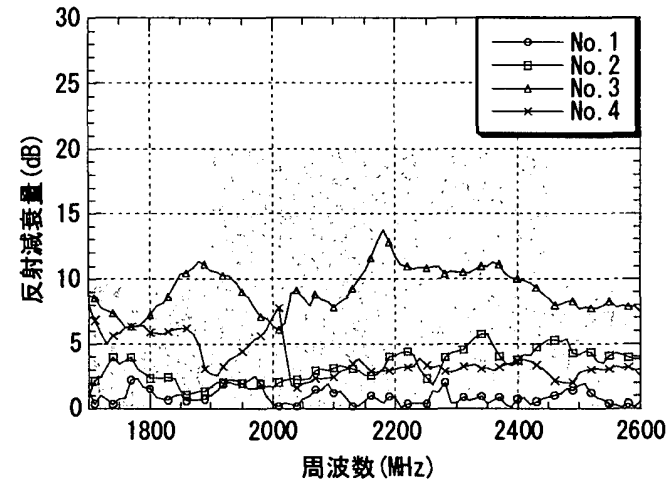

Fig. 4 カーボン混入リサイクルボード

(No. $1 \sim 4$ )の反射減衰量
減衰量の変化を考察し、淮マイクロ波帯の電波吸収体に適した調合 を見いだす。

作製する電波吸収リサイクルボードは、（1）カーボン混入リサイ クルボード、（2）フェライト混入リサイクルボード、(3) カーボン・ フェライト混入リサイクルボードの 3 種類とする。リサイクルボー ドの調合表を Table1に、カーボンどフェライトの組成を Table2 と Table3に示す。供試体の厚さは $15 \mathrm{~mm}$ とし、1700MHz から $2600 \mathrm{MHz}$ の 周波数帯域における反射減衰量を求める。また、良好な結果を得た ボードについては、ボードの厚さを $10 \mathrm{~mm} 、 12.5 \mathrm{~mm} 、 17.5 \mathrm{~mm} 、 20 \mathrm{~mm}$ と変えることで反射減衰量の最大值の周波数を $1900 \mathrm{MHz}$ 及び $2450 \mathrm{MHz}$ に移動させることを試みる。

\section{2 実験結果}

(1) カーボン混入リサイクルボード

カーボン混入リサイクルボードの反射減衰量の測定結果を Fig. 4 に示す。No. 3 で最大の反射减衰量を得たが、最大值は $15 \mathrm{~dB}$ 以下にと どまった。図中の網掛けは開発目標の反射减衰量を示す。

(2) フェライト混入リサイクルボード

フェライト混入リサイクルボードの反射減衰量の測定結果をFig. 5 に示す。どのボードにおいてもほとんど反射减衰量が得られなかっ た。カーボンと比較してフェライト単体を粉末として混入した構造

\begin{tabular}{|c|c|c|c|c|c|c|}
\hline No. & カーボン & フェライト & 古組 & P.P. & カーボンの割合 & フェライトの制合 \\
\hline 1 & 97.5 & - & 380.5 & 570.7 & $9.3 \%$ & 0.08 \\
\hline 2 & 195.1 & - & 361.0 & 541.5 & $17.8 \%$ & 0.08 \\
\hline 3 & 304.8 & - & 339.0 & 508.6 & $26.4 \%$ & $0.0 \%$ \\
\hline 4 & 381.0 & - & 323.8 & 485.7 & $32.0 \%$ & $0.0 \%$ \\
\hline 5 & 一 & 118.3 & 390.8 & 586.3 & $0.0 \%$ & $10.8 \%$ \\
\hline 6 & - & 236.6 & 381.1 & 571.6 & $0.0 \%$ & $19.9 \%$ \\
\hline 7 & - & 304.8 & 375.6 & 563.4 & $0.0 \%$ & $24.5 \%$ \\
\hline 8 & - & 381.0 & 369.5 & 554.3 & $0.0 \%$ & 29.28 \\
\hline 9 & 96.6 & 96.6 & 373.0 & 559.4 & $8.6 \%$ & $8.6 \%$ \\
\hline 10 & 180.9 & 180.9 & 349.3 & 524.0 & $14.6 \%$ & $14.6 x$ \\
\hline 11 & 239.0 & 239.0 & 333.1 & 499.6 & $18.2 \%$ & $18.2 x$ \\
\hline 12 & 255.5 & 255.5 & 328.4 & 492.7 & $19.2 \%$ & $19.2 \%$ \\
\hline 13 & 278.5 & 278.5 & 322.0 & 483.0 & $20.4 \%$ & $20.4 \%$ \\
\hline 14 & 308.4 & 308.4 & 313.6 & 470.5 & $22.0 \%$ & $22.0 \%$ \\
\hline 15 & 356.3 & 356.3 & 300.2 & 450.4 & $24.4 \%$ & 24.48 \\
\hline
\end{tabular}
では電波吸収特性は小さい。

Table1＼cjkstart電波吸収リサイクルボードの調合表（質量比）

Table2 カーボンの組成（質量比％） Table3 フェライトの組成（筫量比％)

\begin{tabular}{|c|c|c|c|c|}
\hline $\mathrm{C}$ & 0 & $\mathrm{~S}$ & $\mathrm{Ca}$ & $\mathrm{Fe}$ \\
\hline 69.5 & 30.1 & 0.31 & 0.03 & 0.03 \\
\hline
\end{tabular}$\quad \quad$\begin{tabular}{|c|c|c|c|c|}
\hline $\mathrm{Fe}_{2} \mathrm{O}_{3}$ & $\mathrm{Ni0}$ & $\mathrm{Zn0}$ & $\mathrm{Cu} 0$ \\
\hline 48.6 & 9.3 & 33.7 & 8.4 \\
\hline
\end{tabular}

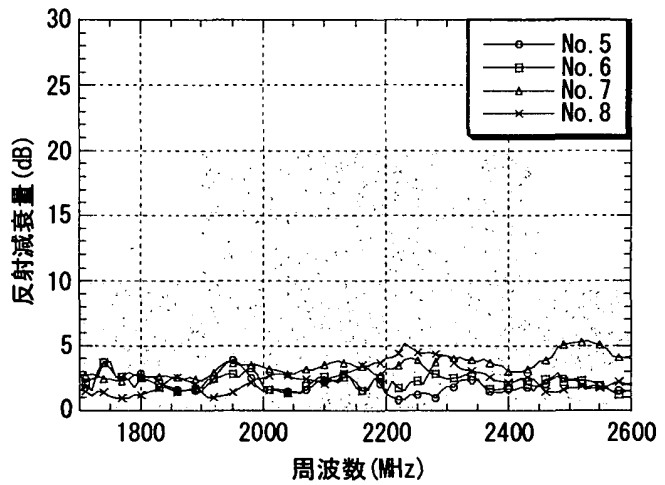

Fig. 5 フェライト混入リサイクルボード (No. $5 \sim 8$ ) の反射減衰量 


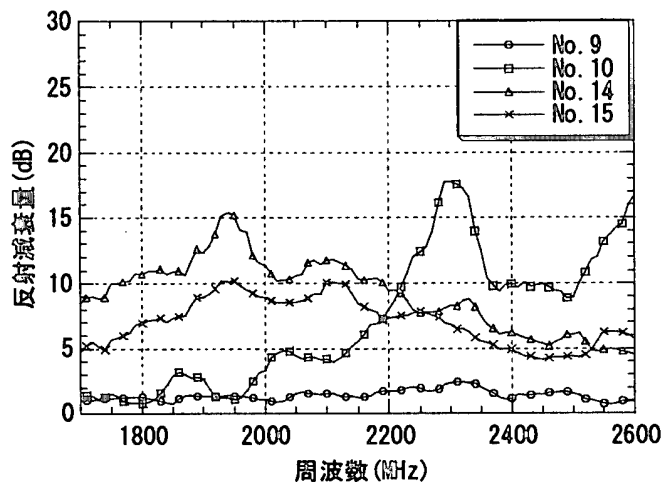

Fig. 6 カーボン・フェライト混入リザイルルポード (No. 9、10、14、15) の反射減㪇量

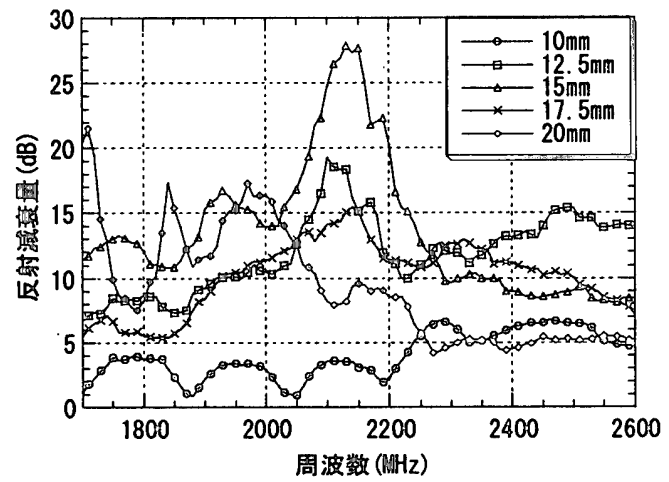

Fig. 8 カーボン。フェライト混入リサイクルボード

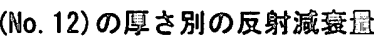

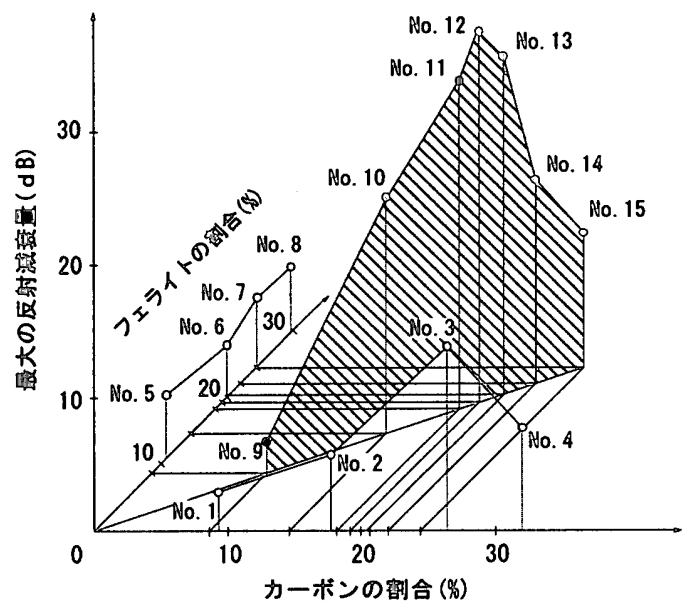

Fig. 10 カーボンとフェライトの混入割合と 反射減蛪量の最大值
（3）カーボン・フェライト混入リサイクルボード

カーボン・フェライト混入リサイクルボードの反射减衰量の測定 結果をFig. 6 〜 9示す。混入量の過少による電波の挢過が原因と 考えられるNo. 9 では全く反射減衰量が得られず、No. 10 では少々効 果があった。No.11、12、13 は、比較的大きな反射减衰量を得るこ とができた。誘電体と磁性体を混合することで反射減衰量が增加し たと思われる。電波吸収材料の混入量の過多による電波の反射が原 因と考えられるNo. 14、15 の調合の反射減衰量は減少した。

次に、良好な結果を得た No. 11、12、13に関して、ボードの厚さ を変えて反射減衰量を測定した。Fig. 7〜9に示す様に全ての調合 に関してボード厚さ $15 \mathrm{~mm}$ で高い反射減衰量を示し、最大值で $25 \mathrm{~dB}$

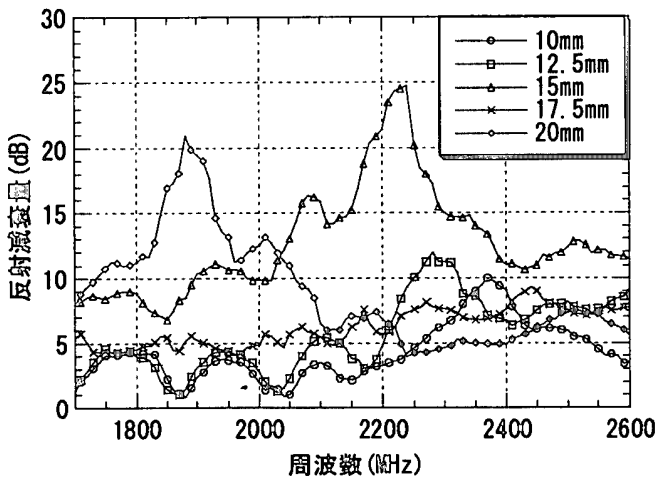

Fig. 7 カーボン・フェライト混入リサイクルボード (No.11)の厚さ別の反射減衰量

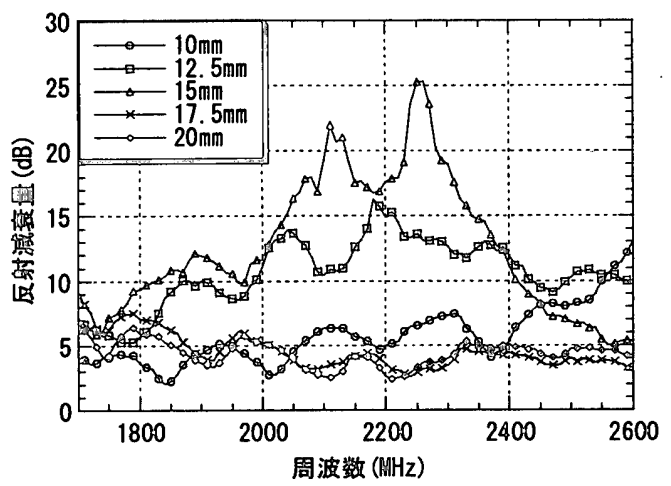

Fig. 9 カーボン・フェライト混入リザイクルボート゚

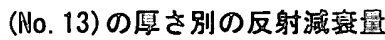

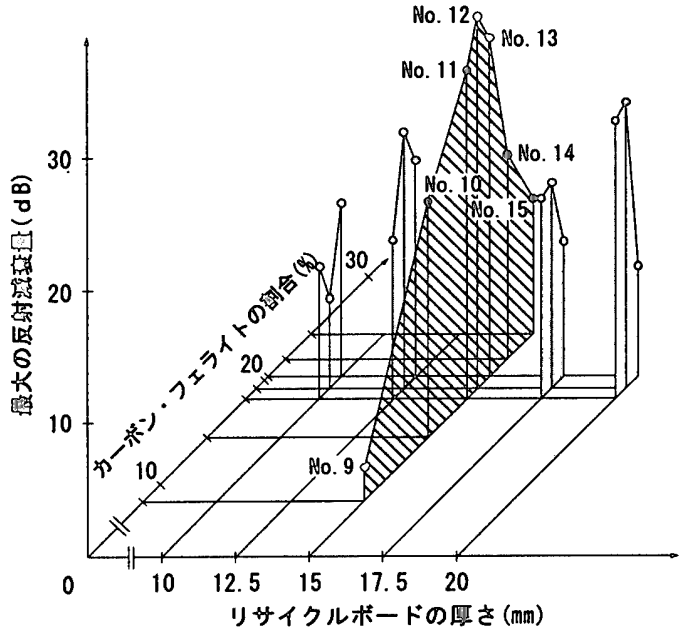

Fig.11 カーボン。フェライト混入リサイクルボードの 厚さによる反射浱衰量の最认值

を超える良好な結果が得られた。また、ボード厚さ $15 \mathrm{~mm}$ 衰量の最大值の周波数が $2200 \mathrm{MHz}$ 周辺に集中している。ボードを厚 くすることで反射堿衰量の最大值の周波数が低周波数側人移動した。 混入割合が一定のため、ボードの厚さを薄くする場合は混入量の減 少に伴う電波の透過、ボードを厚くする場合は混入量の増加に伴う 電波の反射により良好な結果とはならなかった。今回の実験中で唯 一であるが、№.11のボード厚さ $20 \mathrm{~mm}$ で $1900 \mathrm{MHz}$ の反射减衰量のピー クが $20 \mathrm{~dB}$ 以上と開発の目標值を得ることができた。

\section{3 突䮑の薄察}

Fig. 10 にカーボンとフェライトの混入割合と反射減衰量の最大 值を示す。今回の実験のカーボン・フェライト混入リサイクルボー 


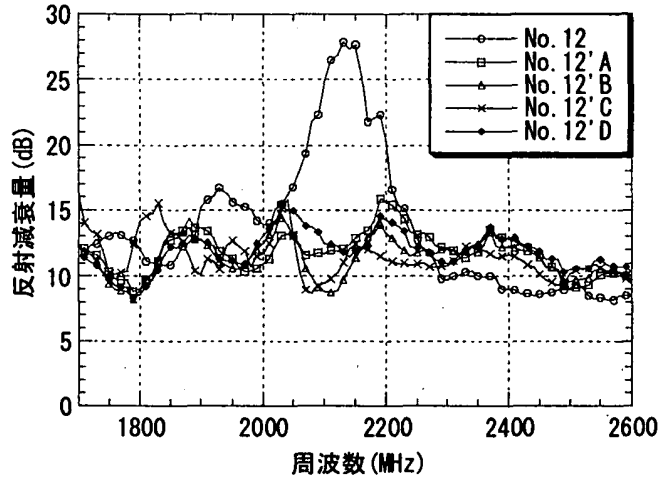

Fig. 12 小型電波吸収リサイクルボードNo. 12 と 大型電波吸収リサイクルボードNo. 12' の反射隇衰量の比較

ドではカーボンとフェライトの混入割合を 1 対 1 とし、この結果を 図中の斜線部に示している。それぞれの混入率 $20 \%$ 前後の No. 11、 12、13において、反射减衰量の最大值のピークが見られた。

Fig. 11にカーボン・フェライト混入リサイクルボードの厚さの違 いによる反射减衰量の最大値を示す。No. 11、12、13のリサイクル ボードの厚さを変化させた結果、反射堿衰量の最大值はボードの厚 さが $15 \mathrm{~mm}$ の場合、大きいことが分かる。これらの図は電波吸収りサ イクルボードの調合設計に活用できると考える。

\section{5. 大型電波吸収リサイクルボード}

\section{1 実験内容}

前章の平行二線線路測定法により良好な反射堿衰量を示したカー ボン・フェライト混入リサイクルボードの中でNo. 12 と 13 の 2 種類 の調合において $600 \times 1800 \times 15 \mathrm{~mm}$ の大型電波吸収リサイクルボー ドを作製する。なお、大型ボードの名称はそれぞれ No. 12'、13’ と する。この大型電波吸収リサイクルボードの任意の位置から切り出 した $70 \times 120 \times 15 \mathrm{~mm}$ の小型電波吸収リサイクルボードの電波吸収 特性を平行二線線路測定法で測定する。切り出す供試体数はそれぞ れAからDの 4 個とする。

\section{2 測定結果及び考察}

大型電波吸収リサイクルボードの任意の位置から切り出した供試 体で測定した平行二線線路測定法による電波吸収特性をFig. 12 と 13 に示す。前章の同一調合の小型電波吸収リサイクルボードの平行 二線線路測定法による電波吸収特性と、1700MHzから $2600 \mathrm{MHz}$ の周波 数範囲において $10 \mathrm{~dB}$ 以上の反射减衰量でほぼ同等の電波吸収特性を 得ることができた。ただし、大型化の製造により、反射堿衰量の最 大值は若干低下した。

\section{6.おわりに}

周波数 $1700 \mathrm{MHz}$ から $2600 \mathrm{MHz}$ までの準マイクロ波帯において、フェ ライトやカーボンを混入した電波吸収リサイクルボードを作製し、 以下のことが分かった。

1）プラスチック廃棄物と古紙を利用したリサイクルボードに、電 波吸收材料としてカーボンとフェライトを混入した準マイクロ波帯 用の電波吸収リサイクルボードを作製した。

2）小型電波吸収リサイクルボードを試作し、平行二線線路測定法 を用いて電波吸収特性を測定した。この結果、電波吸収材料の混入 量が少ないと電波を透過し、反射减衰量は小さくなる。混入量を增

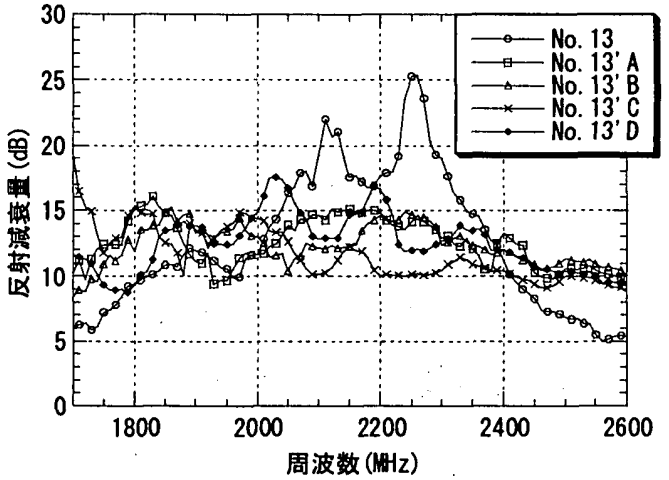

Fig. 13 小型電波吸収リサイクルボードNo.13 と 大型電波吸収リサイクルボードNo. 13'の反射減衰量の比較

やすことで良好な電波吸収特性を得られるが、混入量が多過ぎると 電波を反射し、反射减衰量は小さくなる。

3）カーボンとフェライトの混入割合を 1 対 1 として、それぞれの 混入率 $20 \%$ 前後のボード厚さ $15 \mathrm{~mm}$ のカーボン・フェライト混入リ サイクルボードの反射減衰量の最大值は大きかった。

4）大型電波吸収リサイクルボードを作製し、平行二線線路測定法 を用いて電波吸收特性を測定した。大型ボードから切り出した供試 体と小型電波吸収リサイクルボードの平行二線線路測定法による電 波吸收特性は、ほぼ同等の特性を得ることができた。大型電波吸収 リサイクルボードは、1700MHzから $2600 \mathrm{MHz}$ の広带域で反射減衰量が $10 \mathrm{~dB}$ 以上の良好な電波吸収特性を得ることができた。

今後は、電波暗室において斜め入射特性等の実験を行いたい。 謝 辞 リサイクルボードの開発は名古屋工業大学河辺研究室、高 橋研究室、株式会社トピアの共同研究で行いました。高橋清久教授、 永田謙二助手、高桑芳樹氏、本学卒業生観田典明氏に謝意を表しま す。ご指導頂きました前学長岡島達雄工学博士に谢意を表します。

\section{参考文献}

1）河辺伸二、池田哲夫、安川猛行 ; フェライト及びカーボン混入セメント モルタルの準マイクロ波吸収特性に関する研究、日本建築学会構造系論文 集、No. $567 、$ pp. $1 \sim 5 、 2003.5$

2）河辺伸二、池田哲夫、観田典明；平行二線線路による準マイクロ波带電 波吸収特性の測定方法、日本建築学会構造系論文集、No. 567、pp. $7 \sim 11$ 、 2003. 5

3）河辺伸二、高橋清久、承田謙二、小西正夫、小野田有希久、高桑芳樹; プ ラスチック廃棄物と古紙によるリサイクルボードの開発、日本建築仕上学 会大会学術講演会研究発表論文集、pp. $145 \sim 148 、 2002.9$

4）河辺伸二、下釜一男、池田哲夫、岡島達雄 ; フェライト混入モルタルの TV 電波吸収特性に関する研究 フェライトとカーボンファイバシート.の 複合体の検討、日本建築学会構造系論文集、No. 532、pp. $1 \sim 5 、 2000.6$

5). 河辺伸二、池田哲夫、安川猛行、下釜一男; 準マイクロ波帯におけるカー ボン混入セメントモルタルの電波吸収特性、セメント・コンクリート論文 集、No. 53、pp. $951 \sim 957 、 2000.2$

6）河辺伸二、池田哲夫、下釜一男、安川猛行; 淮マイクロ波帯におけるフェ ライト混入セメントモルタルの電波吸収特性、セメント・コンクリート論 文集、No. $52 、$ pp. $948 \sim 953 、 1998.12$

7）池田哲夫、河辺伸二、下菳一男、岡島達雄 ; 平行二線線路による鉄筋コ ンクリートの T V 電波吸収特性の测定、日本建築学会構造系論文集、 No. $512 、$ pp. $1 \sim 6 、 1998.10$

8）池田哲夫、河辺伸二、岡島達雄；平行二線線路によるTV電波吸収特性の 测定方法の提案、フェライト混入モルタルの TV 電波吸収特性に関する研 究、日本建築学会構造系論文集、No. 496、pp. $17 \sim 22 、 1997.6$

9）清水康敬他；電磁波の吸収と遮蔽、日経技術図書（株）、1989.1

10）内藤喜之；電波吸収体、オーム社、1987.4

（2003年11月10日原稿受理，2004年 1 月 27日採用決定） 